\title{
Burden of disease: A scoping review of HIV/AIDS and TB in occupational noise-induced hearing loss
}

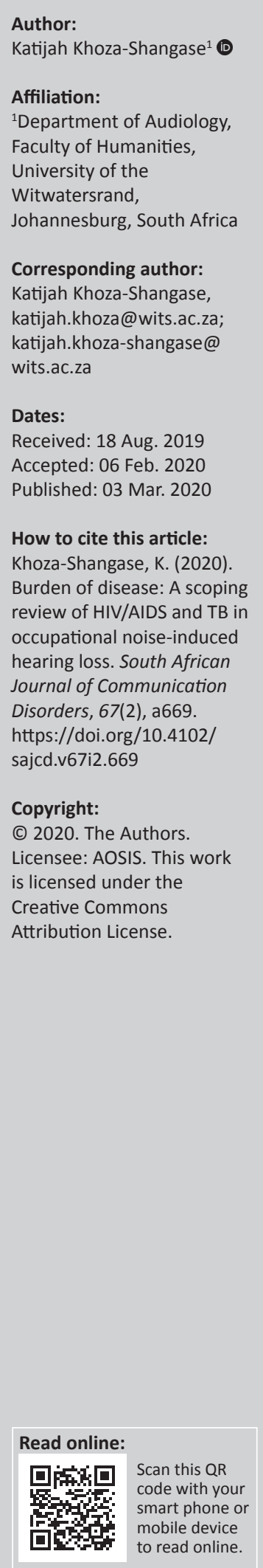

Background: Occupational noise-induced hearing loss (ONIHL) does not occur in isolation from other influencing factors such as health conditions and illnesses like human immunodeficiency virus and acquired immunodeficiency syndrome (HIV and AIDS), as well as tuberculosis (TB). How the burden of disease influences the occurrence and / or management of ONIHL becomes a key if the goal of hearing conservation programmes (HCPs) is to be achieved within these contexts.

Objectives: The purpose of this scoping review was to conduct an investigation on how the burden of disease's influence on ONIHL is reported in literature, with a specific focus on the most prevalent diseases in South African mines - HIV and AIDS and TB.

Method: A scoping review was conducted using the Arksey and O'Malley's framework. A search was conducted in five electronic bibliographic databases and the grey literature.

Results: The search procured 10 publications, with two specific to ONIHL within the South African context. In addition to the two publications specific to TB and ONIHL, findings revealed a serious gap in the evidence around the scoping review question globally. This obvious lack of investigations into the influence of these two conditions in the South African mining context raises serious implications about the responsiveness, and proactive nature of HCPs within this population.

Conclusion: Considering the burden of diseases on otology and audiology is critical as certain diseases cause hearing impairment either as a primary effect, as a secondary/opportunistic effect or as a side effect of treatment options for that disease. An employee suffering from any such disease with concomitant exposure to hazardous noise levels presents an even bigger challenge to HCPs if such is not taken into consideration in the conception, implementation and monitoring of HCPs.

Keywords: Africa; Conservation; Disease; HIV and AIDS; Health; Hearing; Noise; Occupational; Burden; Tuberculosis.

\section{Introduction}

Evidence indicates that South Africa remains one of the low- and middle-income (LAMI) countries with poor health outcomes and high mortality rates linked to the unique quadruple burden of disease (Institute for Health Metrics and Evaluation [IHME], 2018; Pillay-van Wyk et al., 2016; Rohde et al., 2008). Occupational health conditions in this context occur within this unique quadruple burden of diseases; hence, they cannot be seen and managed in a manner that is dissociated from this burden of disease. This is particularly true in occupational noise-induced hearing loss (ONIHL), which has numerous influences linked to the quadruple burden of disease (Khoza-Shangase 2019a).

Freeman (n.d.) argues that it is necessary to prioritise health conditions in South Africa because of the reality that there are limited resources, including financial and human resources, to address all health challenges. This author asserts that it is therefore crucial to focus energies and resources, otherwise nothing could be carried out properly to address healthcare challenges in the country. Putting additional resources into priorities and getting the systems and processes in place for a limited number of conditions could make a difference than trying to do everything at once, and this is the position adopted in the current scoping review where within the context of ONIHL, human immunodeficiency virus (HIV)/acquired immunodeficiency syndrome (AIDS) and tuberculosis (TB) have been prioritised as key diseases in the quadruple burden of diseases relevant within the 
context of South African mining industry. Adams, Ehrlich, Ismail, Quail, and Jeebhay (2018) support this position when they state that healthcare workers in the South African workforce are at risk of the rising TB because of their occupational activity and exposure to as members of communities with a high HIV and TB burden, with an increasing risk of multidrug-resistant TB.

Occupational noise-induced hearing loss is a globally prevalent condition, classified as the number one work-related disability, second only to presbycusis as a form of acquired hearing loss (Krishnamurti, 2009; Mostaghaci et al., 2013). This disability is characterised by a sensorineural partial or complete loss of hearing that develops gradually over a period of several years because of exposure to continuous or intermittent high levels of noise or hazardous levels greater than 85 dBA during an 8-h shift at workplace (Patel et al., 2010; Rappaport \& Provencal, 2001; Ritzel \& McCrary-Quarles, 2008). Evidence indicates that the influence of exposure to high levels of noise during their work life extends past their period of employment, as older people with presbycutic hearing loss have been found to suffer even more severe consequences if they have been exposed to high levels of noise during their working life (Mostaghaci et al., 2013; Ritzel \& McCrary-Quarles, 2008). This is particularly established in developing countries (Chadambuka, Mususa, \& Muteti, 2013; Miah, Rubya, \& Kabir, 2014; Nandi \& Dhatrak, 2008) where additional burden of disease complicates the presentation (Khoza-Shangase, 2019a).

Global estimates of the prevalence of ONIHL have indicated rapidly increasing numbers. Nelson, Nelson, ConchaBarrientos, and Fingerhut (2005) provided global estimates ranging between $7 \%$ and $21 \%$, with Feder and colleagues (2017) recently revising these to be between $16 \%$ and $24 \%$. This increase in prevalence of ONIHL has been reported to be greater in LAMI countries (Chadambuka et al., 2013; Feder et al., 2017; Strauss, Swanepoel, Becker, Eloff, \& Hall, 2014). Specific to South African mines, the only evidence available confirms this conclusion, with Edwards, Dekker, Franz van Dyk, and Banyini (2011) reporting that approximately 73.2\% of the workforce was exposed to noise levels above the legislated occupational exposure level of $85 \mathrm{dBA}$, and Chamber of Mines, as cited by Strauss et al. (2014), reporting that 3.1 out of every 1000 workers have ONIHL. Strauss and colleagues (2014) argue that over and above occupational noise exposure, within the South African context, these figures could be influenced by biological factors as well. These factors include smoking (Fabry et al., 2010), age, gender (Daniel, 2007), genetics (Lavinsky et al., 2016), ototoxic drugs and illnesses such as TB (Assuiti, Lanzoni, dos Santos, Erdmann, \& Meirelles, 2013; Khoza-Shangase, 2019a). Recently, Khoza-Shangase (2019a) has found that goldminers with a history of TB treatment have worse hearing thresholds in high frequencies when compared to those without having TB history. Thus, this author highlights the importance of strategic hearing conservation programmes (HCPs), including ototoxicity monitoring in miners with a history of
TB and HIV / AIDS, and the possible use of oto-protective/ chemo-protective agents in the South African mining population (Khoza-Shangase, 2010a, 2010b, 2011, 2017).

Stuckler and colleagues $(2011,2013)$ argue that South Africa is amongst the countries with the highest incidence of HIV/ AIDS and TB, with the highest prevalence of these diseases in the mining industry. This is because of the fact that TB within the South African context has been shown to grow dramatically, and has been correlated with the increased prevalence of HIV (Chaisson \& Martinson, 2008). A report by Reddy and Swanepoel (2006) has stated that in the South African mining sector, approximately one-third of mineworkers acquired HIV within 18 months of being employed at the mines. Another report by AngloGold Ashanti (2012) West Wits mining district provided estimates of approximately $85 \%$ of their employees with a diagnosis of TB and HIV. Owing to the documented evidence of the compounding impact of synergistic effects of concomitant exposure to ototoxic medications used to treat HIV/AIDS and/or TB and noise (Khoza-Shangase, 2019a; Valente, Hosford-Dunn, \& Roeser, 2008), the implications of the coexistence of these burden of diseases within a chronic noise exposure environment require investigation, quantification and deliberation within HCPs.

Despite the significant progress made through various programmes, such as roll out of antiretroviral therapy (ART), to reduce deaths related to HIV and improve life expectancy (Gueler et al., 2017; Joint United Nations Programme on HIV/AIDS [UNAIDS], 2018), HIV continues to increase, particularly in LAMI countries with increasing evidences of new infections (World Health Organisation [WHO], 2018). In South Africa, the prevalence of HIV almost doubled from 4.25 million in 2002 to 7.52 million in 2018 (Statistics South Africa, 2018). Hence, South Africa has become an epicentre of HIV/AIDS with a combined high rate of TB co-infection, with links having been established between treatments of these conditions and ototoxicity (Khoza-Shangase, 2019b). Owing to high numbers of patients currently on long-term treatment of TB, it is said that South Africa is '...p potentially facing the risk of a significant proportion of the population acquiring aminoglycoside-induced permanent hearing loss' (Bardien, Schaaf, Fagan, \& Petersen, 2009). In 2017, a News24 article by Singh (2017) reported that 123 TB patients in KwaZulu-Natal (KZN) had gone deaf following TB treatment. In this article, the reason cited for the patients going deaf was negligence by the Department of Health: '... as their TB treatment was not properly monitored causing a complete loss of hearing'.

As part of HCPs, it is important that monitoring and management of ototoxicity in HIV / AIDS and TB is added as an important aspect of hearing conservation strategy. The need for audiometric testing to identify early changes in hearing thresholds resulting from drug therapy is felt by this population, giving careful cognisance to the concomitant exposure to excessive occupational noise. Within HCPs, if 
ototoxicity monitoring does not form part of the treatment, employees' hearing outcomes could be far worse (KhozaShangase, 2019a) as they would not be benefitted from various treatment options, including alternative drugs, reduced dosages or altered treatment regimens, although ototoxicity is detected early during the treatment period (Lonsbury-Martin \& Martin, 2001). Furthermore, removal of employee from noisy areas during ototoxic treatment to avoid the synergistic impact of noise and medications on the ear is not carried out, thus exposing the worker to higher risks.

\section{Methods}

Adhering to the methodology advocated by Levac, Colquhoun, and O'Brien (2010), the research team comprising two researchers working in the field of preventive audiology, which includes ONIHL and HCPs, agreed on a broad research question to be addressed by scoping review and overall study protocol, including specification of search terms/keywords / phrases as well as selection of databases to be searched. The framework adopted was that of Arksey and O'Malley (2005), and it specifies five key phases: (1) identifying the research question, (2) identifying relevant publications, (3) study selection, (4) charting the data and (5) collating, summarising and reporting the results.

\section{Research question}

The broad question that directed the current review was, 'Does ONIHL research consider the burden of HIV/AIDS and TB as a potential influence in HCPs, and what has been documented in the literature on this?' This question was guided by the high prevalence of HIV / AIDS and TB in South Africa and particularly in the mining sector of South Africa. The researcher aimed to perform this review to integrate and map available evidences for identification of existing lacunae that could be influencing the success or lack thereof of HCPs within the South African mining industry. Furthermore, influenced by Daudt, van Mossel, and Scott (2013) on the value of scoping reviews, the current review also revealed the types and sources of evidence available on the abovementioned question; all of these reviews would have implications for academic and clinical training, clinical practice, policymaking as well as future research.

\section{Data sources and search strategy}

The initial search was carried out on 18 April 2019 in the following five electronic databases: Science Direct, PubMed, Scopus Medline, ProQuest and Google Scholar. The databases were selected to be comprehensive and to cover publications considering the influence of the burden of disease (HIV/ AIDS and TB) in ONIHL and HCPs. The selected studies were restricted to the studies published in English, with a focus on these two major burdens of diseases in this population. The search consisted of the following terms: Africa, conservation, disease, HIV/AIDS, health, noiseinduced hearing loss, occupational, burden, impact, effects, developing countries, mines and tuberculosis.
Applying the same search process/string that was used in Science Direct, PubMed, Scopus Medline and ProQuest, a web search was conducted in Google Scholar to identify grey literature. Then a priori decision was made to screen only the first 10 hits (as sorted by relevance by Google Scholar) after considering the time required to screen each hit and because it was believed that further screening was unlikely to yield more relevant articles (Stevinson \& Lawlor 2004). The following websites were also searched manually: The Mine Health and Safety Council; Minerals Council South Africa and Department of Mineral Resources.

The following citations, as shown in Table 1, were eventually included: Adams et al. (2018); Barwise, Lind, Bennett, and Martins (2013); Brits, Strauss, Eloff, Becker, and de Swanepoel (2012); Edwards (2009); Eisler (2003); Elgstrand and Vingård (2013); Khoza-Shangase (2019a); Kistnasamy et al. (2018); Minerals Council of South Africa (2018) and Sibanye Gold (2018). Snowball sampling was adopted where citations, meeting the inclusion criteria, within articles were searched. Another search of the above-mentioned bibliographic databases and grey literature was conducted in August 2019 to ascertain if there were any additional publications post the initial search. No new hits were identified.

\section{Citation management}

All citations were imported into the web-based bibliographic manager Endnote. Duplicate citations were removed manually. Further duplicate citations if found were removed during title and abstract relevance screening and data characterisation of full articles.

\section{Eligibility criteria}

The researchers adopted a two-stage screening process to evaluate the applicability of publications identified in the search. The first stage involved the inclusion of publications containing keywords and phrases and those broadly describing the influence/inclusion of HIV/AIDS and/or TB (burden of disease) in ONIHL and/or HCPs to determine and characterise the existing evidence base on the impact of the burden of disease in ONIHL. The second stage involved excluding from analysis the publications that described HIV/AIDS and/or TB and hearing loss in areas other than ONIHL; however, reference lists from these publications were reviewed to identify additional relevant publications. Owing to limited resources for translation, only English publications were included.

\section{Title and abstract relevance screening}

For efficient time management and as recommended by Arksey and O'Malley (2005), the first level of inspection of the evidences involved reviewing only the titles of the manuscripts. The second level included reviewing the abstracts only. Finally, entire articles were reviewed (refer to Figure 1). This ensured that resources were not wasted for procurement of articles that did not meet the minimum inclusion criteria of this review. The researchers used the 
TABLE 1: Studies reflecting burden of disease in occupational noise-induced hearing loss and its management.

\section{and date}

occupational

lung disease

acquired in

South African

mines: Recent

and ongoing

challenges.

quantify shortfalls and explore

underlying challenges.
This study aimed to assess

developments over the last 5 years

in providing compensation,

\section{Methodology}

Review

Context

South Africa

Results

By the end of 2017, 111166 miners had received

compensation (of which 55864 were for permanent

lung impairment, and another 52473 for tuberculosis

[TB]); however, 107714 compensable claims remained

unpaid. Many $(28.4 \%)$ compensable claims are from

Mozambique, Lesotho, Swaziland, Botswana and

elsewhere in southern Africa, a large proportion of

which have been longstanding. A myriad of diverse

systemic barriers persist, especially for workers and

their families outside South Africa. Calculating

predicted burden of occupational lung disease

compared to compensable claims paid suggests a

major shortfall in filing claims in addition to the large burden of still unpaid claims.

al. (2013) action to address HIV and TB in Mozambique's

cross-border

mining sector

Reports new research from 2011

Review

to 2012 on health-related

attitudes and behaviours of

Mozambican mine workers and

their families, and presents an

estimate of the financial burden of

disease related to migrant mine

work for Mozambique's public

services and migrant-sending

communities.

Brits et al. Hearing profile To compare the hearing of

hearing of Audiological and medical

$\begin{array}{ll}\text { of goldminers } & \text { goldminers with and without TB to } \\ \text { with and } & \text { determine the effect of TB and its }\end{array}$

with and

associated risk profile on hearing.

African goldmin of 2698 South

were analysed in a rospective

were analysed in a retrospective

cohort design. Hearing thresholds

for the air conduction frequencies

$(0.5 \mathrm{kHz}, 1 \mathrm{kHz}, 2 \mathrm{kHz}, 3 \mathrm{kHz}, 4$

$\mathrm{kHz}, 6 \mathrm{kHz}$ and $8 \mathrm{kHz}$ ) in both ears

were analysed together with

biographical and occupational

data. Subjects were divided into

two experimental groups (single

TB treatment $[n=911]$ and

multiple TB treatment $[n=376])$

and one control group $(n=1411)$.

Comparisons between groups

included (1) change from baseline

to most recent audiogram, (2)

most recent hearing thresholds

most recent hearing thresholds

and (3) most recent thresholds

unexposed groups.

A retrospective record review of

102 miners' audiological records, 102 miners' audiological records,

$\begin{array}{ll}\text { Khoza- } & \text { Hearing } \\ \text { Shangase } & \text { function }\end{array}$

$\begin{array}{ll}\text { Shangase } & \text { function of } \\ \text { (2019a) } & \text { goldminers }\end{array}$

with and

without a

history of TB

treatment: a

retrospective

The objective of this study was to compare the hearing function of

goldminers with (treatment group) and without (non-treatment group) the history of TB treatment, in order to determine which group had increased risk of noise induced

conducted, with data analysed

both qualitatively and

quantitatively.

Mozambique

They recommend that the Declaration be

operationalised and enforced. Practical measures should include training of health workers in migrants' right to health; user-friendly health information in

Portuguese and local languages; building the advocacy capacity of mine workers' representatives and more attention to social, cultural and economic factors that affect migrant mine workers' health, including better access to health information and services and livelihoods for wives, widows and orphans in communities of origin.

South Africa Hearing thresholds for the TB groups were significantly $(p<0.01)$ elevated compared to the control group, after correcting for time between baseline and most recent audiogram, threshold at baseline and age at recent audiogram, threshold at baseline and age at test. Pair-wise comparisons demonstrated the large threshold differences between the control and
multiple TB group. Changes in mean thresholds across TB treatment groups were independent of noise exposure. Hearing thresholds over time also deteriorated significantly more $(p<0.01)$ in workers with TB (single and multiple treatment) than in workers without TB.

South Africa Findings suggest that goldminers with a history of TB treatment have worse hearing thresholds at high frequencies when con history; with evidence of a noise-induced hearing loss notch at $6000 \mathrm{~Hz}$ in both groups. Pearson's correlations showed values between 0 and 0.3 ( 0 and $-0.3)$, which are indicative of a weak positive (negative) correlation between HIV and hearing loss as well as between hearing loss and age in this population.

two groups was examined.

\begin{tabular}{|c|c|c|}
\hline $\begin{array}{l}\text { Eisler } \\
\text { (2003) }\end{array}$ & $\begin{array}{l}\text { Health risks of } \\
\text { goldminers: A } \\
\text { synoptic } \\
\text { review. }\end{array}$ & $\begin{array}{l}\text { Health problems of goldminers } \\
\text { (decreased life expectancy; } \\
\text { increased frequency of cancer of } \\
\text { the trachea, bronchus, lung, } \\
\text { stomach and liver; increased } \\
\text { frequency of pulmonary TB (PTB), } \\
\text { silicosis, and pleural diseases; } \\
\text { increased frequency of insect- } \\
\text { borne diseases, such as malaria } \\
\text { and dengue fever; noise-induced } \\
\text { hearing loss; increased prevalence } \\
\text { of certain bacterial and viral } \\
\text { diseases and diseases of the blood, } \\
\text { skin and musculoskeletal system) } \\
\text { are briefly documented in } \\
\text { goldminers from Australia, North } \\
\text { America, South America and Africa. }\end{array}$ \\
\hline $\begin{array}{l}\text { Adams et } \\
\text { al. (2018) }\end{array}$ & $\begin{array}{l}\text { Occupational } \\
\text { health } \\
\text { challenges } \\
\text { facing the } \\
\text { Department of } \\
\text { Health: } \\
\text { Protecting } \\
\text { employees } \\
\text { against TB and } \\
\text { caring for } \\
\text { former } \\
\text { mineworkers } \\
\text { with } \\
\text { occupational } \\
\text { health } \\
\text { diseases. }\end{array}$ & $\begin{array}{l}\text { This chapter reviews two } \\
\text { occupational populations for } \\
\text { which the South African } \\
\text { Department of Health has legal } \\
\text { responsibilities, although in } \\
\text { different ways. These are } \\
\text { healthcare workers at risk of TB, to } \\
\text { which the department has } \\
\text { responsibilities as an employer, } \\
\text { and former mineworkers with } \\
\text { occupational lung disease, to } \\
\text { which the department has legal } \\
\text { responsibilities for examination } \\
\text { and compensation under the } \\
\text { Occupational Diseases in Mines } \\
\text { and Works Act (ODMWA). }\end{array}$ \\
\hline
\end{tabular}

Review

In general, HIV infection or excessive alcohol and tobacco consumption tended to exacerbate existing health problems. Miners who used elemental mercury to amalgamate and extract gold were heavily contaminated with mercury. Among individuals exposed occupationally, concentrations of mercury in their air, fish diet, hair, urine, blood and other tissues significantly exceeded all criteria proposed by various national and international regulatory agencies for protection of human health. However, large-scale epidemiological evidence of severe mercuryassociated health problems in this cohort was not demonstrable.

Review Besides infection control and prevention requires an integrated management system that incorporates commitment from top management; comprehensive, locally appropriate and practicable policies; appropriate training; continued surveillance and the provision of comprehensive occupational health services to healthcare workers.

The Department of Health has major shortcomings in fulfilling its legal mandate of providing statutory medical examinations (in addition to the treatment of TB and HIV-related disease in all public healthcare facilities). The department is also failing to adjudicate and arrange for the payment of compensation to workers with occupational lung disease. Legal, financial and managerial reform of the ODMWA system is required. 
TABLE 1 (Continues...): Studies reflecting burden of disease in occupational noise-induced hearing loss and its management.

\begin{tabular}{|c|c|c|c|c|c|}
\hline $\begin{array}{l}\text { Author(s) } \\
\text { and date }\end{array}$ & Publication title & Publication focus/aims & Methodology & Context & Results \\
\hline $\begin{array}{l}\text { Elgstrand } \\
\text { and } \\
\text { Vingård } \\
\text { (2013) }\end{array}$ & $\begin{array}{l}\text { Occupational } \\
\text { safety and } \\
\text { health in } \\
\text { mining: } \\
\text { Anthology on } \\
\text { the situation in } \\
16 \text { mining } \\
\text { countries. }\end{array}$ & Book & - & - & - \\
\hline $\begin{array}{l}\text { Edwards } \\
\text { (2009) }\end{array}$ & $\begin{array}{l}85 \mathrm{dBA}: \text { Is it } \\
\text { protective } \\
\text { enough to } \\
\text { prevent } \\
\text { hearing loss in } \\
\text { South African } \\
\text { miners? }\end{array}$ & $\begin{array}{l}\text { To test the hypothesis: The } \\
\text { occupational exposure limit (OEL), } \\
\text { which does not take into account } \\
\text { complex exposure patterns, may } \\
\text { not provide adequate protection } \\
\text { for miners' ears. }\end{array}$ & $\begin{array}{l}\text { A pilot study to evaluate impact on } \\
\text { the inner ear used otoacoustic } \\
\text { emissions as a measure of stress } \\
\text { to the cochlea was undertaken. } \\
\text { Controlled exposure to noise, heat } \\
\text { and exercise on a group of young } \\
\text { healthy males and females was } \\
\text { conducted using less than the } \\
\text { prescribed OEL for noise. Pre- } \\
\text { exposure and post-exposure } \\
\text { otoacoustic measurements were } \\
\text { compared to evaluate the impact } \\
\text { of individual and combined } \\
\text { exposures. }\end{array}$ & South Africa & $\begin{array}{l}\text { Statistically significant differences were found } \\
\text { between the pre-exposure and post-exposure } \\
\text { otoacoustic measurements for noise as a stressor. } \\
\text { Exposure to other health stressors did not appear to } \\
\text { accentuate the effect on the cochlea. } \\
\text { The results appear to indicate that further } \\
\text { investigation of the current OELs and the methods and } \\
\text { aspects being measured is needed. }\end{array}$ \\
\hline $\begin{array}{l}\text { Minerals } \\
\text { Council } \\
\text { South } \\
\text { Africa } \\
\text { (2018) }\end{array}$ & $\begin{array}{l}\text { Masoyise iTB } \\
\text { Project: } \\
\text { Minerals } \\
\text { Council South } \\
\text { Africa } \\
\text { Masoyise iTB } \\
\text { project data } \\
\text { report } 2018 .\end{array}$ & $\begin{array}{l}\text { To track progress on concerned } \\
\text { illnesses using the Minerals } \\
\text { Council Health Information } \\
\text { Management System (Minerals } \\
\text { Council-HIMS) on the } \\
\text { Healthsource platform. } \\
\text { To collate data on key threshold } \\
\text { indicators from members, validate } \\
\text { and evaluate performance against } \\
\text { industry health and safety } \\
\text { milestones and produce annual } \\
\text { reports on performance. }\end{array}$ & $\begin{array}{l}\text { Data used in this report were } \\
\text { drawn from the Minerals Council } \\
\text { (HIMS) database and the analysis } \\
\text { was performed using the Excel } \\
\text { spreadsheet to reflect the } \\
\text { performance of the industry and } \\
\text { commodities against key } \\
\text { indicators as reflected on the } 30 \\
\text { April 2019. Companies upload } \\
\text { their TB and HIV data on the } \\
\text { system on a quarterly basis and } \\
\text { the annualised data only at year- } \\
\text { end. The system prioritised } \\
\text { compliance to reporting } \\
\text { requirements to ensure that } \\
\text { participating companies uploaded } \\
\text { and finalised their reports prior to } \\
\text { analysis of data. }\end{array}$ & South Africa & $\begin{array}{l}\text { Report focuses on TB and HIV testing, counselling, } \\
\text { treatment and reporting. No mention of impacts of } \\
\text { these conditions on ONIHL. }\end{array}$ \\
\hline $\begin{array}{l}\text { Sibanye } \\
\text { Gold } \\
\text { (2018) }\end{array}$ & $\begin{array}{l}\text { Occupational } \\
\text { health and } \\
\text { well-being: } \\
\text { Sibanye- } \\
\text { Stillwater } \\
\text { Integrated } \\
\text { Report 2018. }\end{array}$ & $\begin{array}{l}\text { Report on occupational health and } \\
\text { well-being of their employees } \\
\text { (individualised care). }\end{array}$ & Report & South Africa & $\begin{array}{l}\text { Report includes findings on ONIHL, TB, HIV - also } \\
\text { testing, counselling, treatment and reporting. No } \\
\text { mention of impacts of these conditions on ONIHL. }\end{array}$ \\
\hline
\end{tabular}

ODMWA, Occupational Diseases in Mines and Works Act; HIV, human immunodeficiency virus; TB, tuberculosis; PTB, pulmonary TB; HIMS, Health Information Management System; ONIHL, occupational noise-induced hearing loss; OEL, occupational exposure limit.

research team's previously developed and pretested abstract relevance screening spreadsheet, which was found to have a reviewer agreement (overall kappa) greater than 0.8 - which is considered to represent a high level of agreement (Viera \& Garret, 2005). The titles, abstracts and entire articles were independently screened by both researchers. For titles where abstracts were not available, the researchers included them for subsequent review of full article during data characterisation phase. The researchers met regularly during entire process to ensure that conflicts were resolved, with author making the final decision where disagreements were found. A high level of agreement was found with the overall kappa of 0.81 .

\section{Data characterisation}

All relevant citations for the current scoping review on HIV/ AIDS and/or TB in ONIHL and HCPs after title and abstract inspection were obtained for later review of full publications. A spreadsheet was developed by the author where relevance of the publication was confirmed and where details of the publication, such as type of publication, author and publication year, title, focus and aims, methodology, context, results/ recommendations and reported challenges, gaps and limitations, were mentioned. The characteristics of each publication were extracted by both researchers. Further publications were excluded at this phase if they did not meet the minimum eligibility criteria. In adherence with Levac et al.'s (2010) framework, the researchers met to resolve any conflicts and ensure consistency between them as well to make sure that the publications were consistent with the set research question and purpose following their independent reviews.

\section{Data summary and synthesis}

The data were compiled in a single spreadsheet and imported into Microsoft Excel 2016 (Microsoft Corporation, Redmond, WA, USA) for descriptive analysis.

\section{Ethical consideration}

This article followed all ethical standards for a research without direct contact with human or animal subjects.

\section{Results and discussion}

Current findings highlight a significant need for research in this area as indicated by paucity of evidence on highly prevalent burden of disease conditions relating to ONIHL and HCPs within the context of Africa and the world. This is despite the available evidence on the influence of HIV / AIDS 
and TB on hearing function within and outside the context of noise exposure (Brits et al., 2012; Cox, Reuter, Furin, \& Seddon, 2017; Khoza \& Ross, 2002; Khoza-Shangase, 2010a, 2019a; Matas, Angrisani, Magliaro, \& Segurado, 2014; Wilson, Tucci, Merson, \& O'Donoghue, 2017). The paucity was found in spite of all evidences pointing towards the synergistic relationship between noise exposure and ototoxic medications (Behar, 2018; European Agency for Safety and Health at Work [EU-OSHA], 2009; Li \& Steyger, 2009). Of the publications deemed potentially relevant for this scoping review, only two South African studies were found that specifically investigated the possible influence of TB treatment on ONIHL in goldminers (Brits et al. 2012; Khoza-Shangase 2019a).

Apart from the two South African studies, nuanced analysis of publications revealed that research in occupational health has not addressed ONIHL as a complex condition that occurs in this context - a condition that does not occur in isolation, and particularly a condition that can be exacerbated by pharmacological treatments that miners receive for occupational health conditions such as TB. This conclusion is drawn from reviewed studies that address health and/or diseases in miners without linking these to each other and to occupational health prevention strategies (such as HCPs for ONIHL). These studies, as shown in Table 1, investigated the following aspects, which the current author believes have implications for the burden of disease influence on HCPs: studies on intensifying action to address HIV and TB in the mining sector; reviews on health risks amongst goldminers; investigations on challenges of occupational health facing the department of health - protecting employees against TB and caring for former mineworkers with occupational health disease; occupational safety and health in mining anthology on situations in 16 mining countries; and studies looking at whether $85 \mathrm{dBA}$ as a regulation point is protective enough to prevent ONIHL in South African miners. All these publications, although speaking on the burden of disease

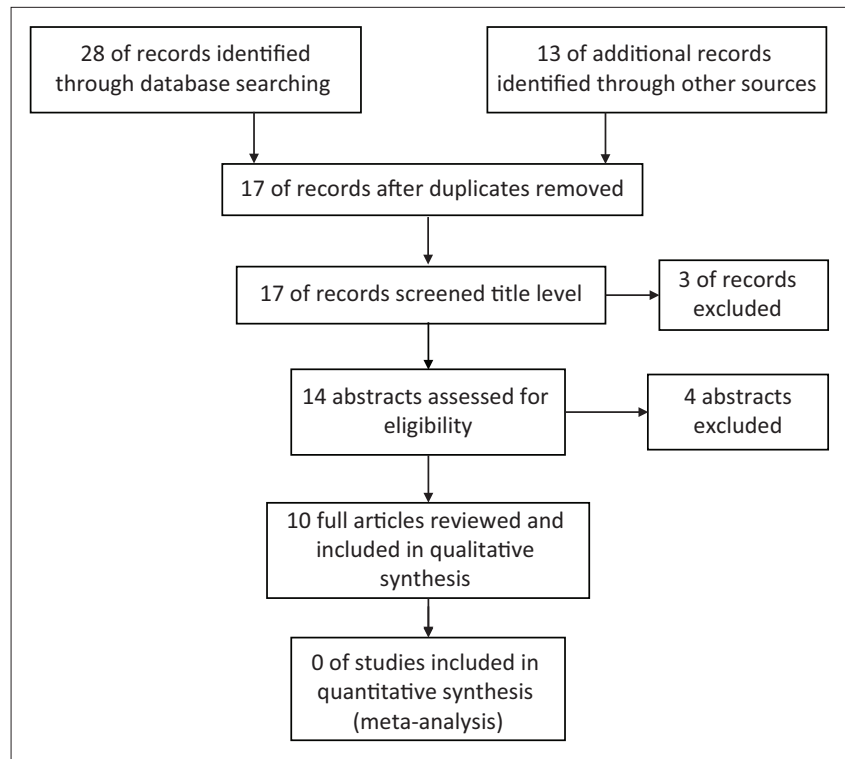

FIGURE1: Preferred Reporting Items for Systematic Reviews and Meta-Analysis (PRISMA) flow diagram for included publications. directly and/or indirectly, are silent on focussing the influence of these on ONIHL.

Barwise et al. (2013), driven by their knowledge of the high burden of HIV / AIDS and TB in LAMI countries, conducted a study in Mozambique, where they analysed the importance of recent policy developments, both regional and national, aimed at intensifying action to address HIV and TB in Mozambique's mining sector. These authors recommend that the country's declaration regarding occupational health be operationalised and enforced. They further report research conducted from 2011 to 2012 on health-related attitudes and behaviours of Mozambican mine workers and their families, and present an estimate of the financial burden of the disease related to migrant mine work for Mozambique's public services and migrant-sending communities. Furthermore, these authors suggested that practical measures, including training of health workers in migrants' right to health; user-friendly health information in Portuguese and local languages; building the advocacy capacity of mine workers' representatives; and giving more attention to social, cultural, and economic factors that affect migrant mine workers' health, including better access to health information and services be put in place. These recommendations are seem to be applicable in the context of South African as well, as evidenced in Kistnasamy et al.'s (2018) study, where they explored recent developments and ongoing challenges to tackle injustices of occupational lung diseases acquired in South African mines. In their assessment of developments over the last 5 years in providing compensation, quantifying shortfalls and exploring underlying challenges with $\mathrm{TB}$ management in South African mines, these authors found that by the end of 2017, 111166 miners had received compensation, of which 55864 were for permanent lung impairment, and another 52473 for TB. This shows significant burden on South African mining sector because of these conditions, and hence a consequent need for practical measures in ONIHL similar to those described in Barwise et al.'s (2013) study. The inferred implications of these studies for possible hearing lossrelated compensation linked to noise exposure with concomitant ototoxicity are significant, with inferences for appropriate HCPs.

As far as reviews on health risks of goldminers are concerned, Eisler (2003) simply documents health problems of goldminers in Australia, North America, South America and Africa. Eisler (2003) identified noise-induced hearing loss amongst conditions such as decreased life expectancy; increased frequency of cancer of the trachea, bronchus, lung, stomach and liver; increased frequency of pulmonary tuberculosis (PTB), silicosis and pleural diseases; increased frequency of insect-borne diseases such as malaria and dengue fever; increased prevalence of certain bacterial and viral diseases; and diseases of the blood, skin and musculoskeletal system. Relationships between these health problems and their possible influence on others are not considered in this review. This is problematic as far as the 
question for this scoping review is concerned, and highlights the failure of mining industry to, for example, consider the affect of ototoxicity arising from treatments for most of these listed health conditions, including cancer (Landier, 2016), TB (Brits et al., 2012; Khoza-Shangase, 2019a) and bacterial and viral diseases, such as HIV/AIDS (KhozaShangase, 2010a, 2017, 2019b). Vulnerability of the inner ear during treatments for the mentioned diseased conditions with concomitant exposure to excessive noise has been documented to worsen presenting ONIHL (Brits et al., 2012; Khoza-Shangase, 2019a; Li \& Steyger, 2009). Exploration of HCPs and health and safety regulations in the mining industry clearly indicate a gap in clinical practice and decision-making concerning management of relevant pillars of HCPs.

Of all the pillars for successful implementation of HCPs, which include periodic noise exposure measurement/monitoring; engineering controls; administrative controls; personal hearing protection; employee/management education, motivation, and training; risk-based medical examination; medical surveillance; and audiometric evaluations as well as recordkeeping (Amedofu, 2007; Hong, Kerr, Poling, \& Dhar, 2013), careful deliberation of employees presenting with health problems, as well as the treatment they are taking to manage these problems, is critical. Key to these 'at risk' employees' HCP could be stricter administrative control, which includes reducing shifts in noisy areas; individualised or more-directed employee motivation and training programmes, including ototoxicity education and monitoring; more frequent and more comprehensive medical surveillance and audiometric evaluations. All this would require the use of a proactive data management system for record-keeping (Jantti \& Cater-Steel, 2017) to be able to proactively track these 'at risk' miners and efficiently monitor key factors, including ototoxicity monitoring and intervention, and provide preventive and intervention measures where required.

Adams et al. (2018), in their investigations on occupational health challenges faced by the Department of Health in South Africa, recommend protection of employees against TB and caring for former mineworkers with occupational health diseases, surprisingly without any mention of the benefits of this recommendation on HCPs and miners' hearing preservation. This publication does not mention ONIHL, and is another example of missed alignment of occupational health disease management. These authors, however, highlight Department of Health's shortcomings in fulfilling its legal mandate of providing statutory medical examinations over and above the treatment of TB and HIV-related disease in all public healthcare facilities. The current author suggests audiological monitoring and intervention as one of these healthcare facilities. Most importantly, Adams et al. (2018) conclude their findings by sounding a crucial requirement for reform (legal, financial and managerial) of the Occupational Diseases in Mines and Works Act (ODMWA). On the contrary, Elgstrand and Vingård (2013), in their study on Occupational Safety and Health in Mining Anthology on situations in
16 mining countries, discussed ONIHL in isolation from the burden of diseases. This lack of viewing employees' health conditions in a comprehensive holistic manner that acknowledges the possible influence that one condition might have on another (specifically in this case HIV / AIDS and TB's influence on ONIHL) is also seen in specific industry annual reports of Minerals Council South Africa (2018) and Sibanye Gold (2018). These reports clearly show intensive efforts to improve the employees' HIV/AIDS and TB status through testing, counselling, treatment and efficient reporting. None of the reports, however, deliberate on and/or mention the possible impact that these conditions have on ONIHL in their employees. Nuanced analysis of the reporting provided in these reports shows that the data management system used by Minerals Council South Africa (2018), Minerals Council Health Information Management System, is such that it shows the employees having 'risk factors' for ONIHL as far as these two burdens of diseases are concerned, and therefore shows the employees in need of close monitoring in their HCPs. However, this could successfully happen only if all mines are compliant with utilising this data management tool, and the current report raises non-compliance of registered companies as one of the challenges, alongside data system quality assurance and the system's functionality limitations.

The closest study arguing for consideration of ONIHL as a complex condition that is influenced by other factors such as chemical exposure, heat and exercise (workload), is the one conducted by Edwards (2009). It questioned whether the occupational exposure limit (OEL) of $85 \mathrm{dBA}$ as a regulation point is protective enough to prevent ONIHL in South African miners. This study, however, found statistically significant differences between pre-exposure and postexposure otoacoustic measurements for noise as a stressor when using $85 \mathrm{dBA}$, but not for other health stressors. These did not appear to accentuate effect on the cochlea. Edwards (2009) concludes by recommending further investigations of 85 dBA OEL. The current author recommends inclusion of the burden of diseased conditions that are the focus of this scoping review in such future studies. This recommendation is bolstered by the only two studies found which specifically examined the possible influence of TB on ONIHL in the context of South Africa.

Brits et al. (2012), in their study on hearing profile of goldminers with and without TB in South Africa, where they compared hearing of goldminers with and without TB to determine the effect of TB and its associated risk profile on hearing, have found that hearing thresholds for TB groups were significantly $(p<0.01)$ elevated compared to the control group, and that hearing thresholds over time also deteriorated significantly $(p<0.01)$ more in workers with TB (single and multiple treatment) than in workers without TB. These findings were recently supported by Khoza-Shangase (2019a) in a retrospective data review study, which also investigated hearing function of goldminers with and without a history of TB treatment. This recent study also 
investigated possible influence of age and HIV in these two groups. Findings from this study suggest that goldminers with a history of TB treatment have worse hearing thresholds in high frequencies when compared with those without this history, with evidence of a noise-induced hearing loss notch at $6000 \mathrm{~Hz}$ in both groups. Furthermore, findings of this study have indicated a weak positive (negative) correlation between HIV and hearing loss as well as between hearing loss and age in this population. Khoza-Shangase (2019a) uses findings from this study to highlight the importance of strategic HCPs, including ototoxicity monitoring, and the possible use of oto-protective/chemo-protective agents in this population.

\section{Conclusions}

Human immunodeficiency virus, TB and cancer are three of South Africa's greatest burdens of disease (Olu et al., 2015). The current scope review revealed paucity of evidence and engagement with the possible influence of HIV/AIDS and TB on ONIHL and HCPs. This is a significant worry considering that mining remains an important industrial sector in many parts of the world, and one of the key sectors in South Africa where HIV/AIDS and TB are significant burdens of disease. Globally, evidence suggests that progress has been made in terms of control and management of occupational health hazards; however, significant room exists for further improvement, especially in LAMI countries, and as far as occupational diseases are concerned for managing ONIHL. Significant room exists for reducing occupational health risks as well as managing and compensating for occupational health conditions. Occupational noise-induced hearing loss risk reduction and management requires carefully conceived and efficiently implemented and monitored HCPs. These HCPs need to be contextually sensitive, responsive and relevant. Such contextualised HCPs for South Africa call for awareness and acknowledgement of the burdens of disease in the form of HIV/AIDS and TB in the presentation of ONIHL. This awareness could only increase the likelihood of success of HCPs that have shown to be less than optimal in achieving the goals of eliminating ONIHL within this context.

Occupational noise-induced hearing loss is a complex condition influenced by a number of factors, with ototoxicity being one of the key factors. Although limited research has been conducted in the synergistic effects of noise and ototoxic medications in the mining industry, sufficient evidence exists for the audiology community to increase their focus on this population and deliberate on how to ensure successful preventive measures are in place to maintain miners' quality of life. Hearing conservation programmes naïve of the burden of disease implications fail to ensure closer monitoring of employees, individualised administrative controls for involved miners and exploration of other protective measures for employees on ototoxic treatments such as oto-protective agents; hence, implications for policy and practice reviews in HCPs are important.

\section{Acknowledgements}

The author wishes to thank Dr N. Moroe, research team member, for contributing towards the title and abstract relevance screening of the scoping review.

\section{Competing interests}

The author declares that she has no financial or personal relationships that may have inappropriately influenced her in writing this article.

\section{Author's contributions}

K.K-S. is the sole author of this research article.

\section{Funding information}

Financial assistance was provided by the National Institute for the Humanities and Social Sciences and the Consortium for Advanced Research Training in Africa.

\section{Data availability statement}

Data sharing is not applicable to this article as no new data were created or analysed in this study.

\section{Disclaimer}

The views and opinions expressed in this article are those of the author and do not necessarily reflect the official policy or position of any affiliated agency of the author.

\section{References}

Adams, S., Ehrlich, R., Ismail, N., Quail, Z., \& Jeebhay, M. (2018). Occupational health challenges facing the department of health: Protecting employees against tuberculosis and caring for former mineworkers with occupational health disease. South African Health Review, 2012(13), 67-82.

Amedofu, G.K. (2007). Effectiveness of hearing conservation program at a large surface gold mining company in Ghana. African Journal of Health Sciences, 14(1), 49-53. https://doi.org/10.4314/ajhs.v14i1.30846

AngloGold Ashanti. (2012). Country Fact Sheet South Africa. Retrieved September 01, 2015 from http://www.aga-reports.com/12/.

Arksey, H., \& O'Malley L. (2005). Scoping studies: Towards a methodological framework. International Journal of Social Research Methodology: Theory and Practice, 8(1), 19-32. https://doi.org/10.1080/1364557032000119616

Assuiti, L.F., Lanzoni, G.M., dos Santos, F.C., Erdmann, A.L., \& Meirelles, B.H. (2013). Hearing loss in people with HIV/AIDS and associated factors: An integrative review. Brazilian Journal of Otorhinolaryngology, 79(2), 248-255. https://doi. org/10.5935/1808-8694.20130042

Bardien, J., Schaaf, H., Fagan, J.J., \& Petersen, L. (2009). Aminoglycoside-induced hearing loss: South Africans at risk. South African Medical Journal, 99(6), 440-441.

Barwise, K., Lind, A., Bennett, R., \& Martins, E. (2013). Intensifying action to address HIV and tuberculosis in Mozambique's cross-border mining sector. International Journal of Health Services, 43(4), 699-719. https://doi.org/10.2190/HS.43.4.g

Behar, A. (2018). Ototoxicity and noise. Journal of Otorhinolaryngology, Hearing and Balance Medicine, 1(2), 10. https://doi.org/10.3390/ohbm1020010

Brits, J., Strauss, S., Eloff, Z., Becker, P.J., \& de Swanepoel, W. (2012). Hearing profile of goldminers with and without tuberculosis. Occupational and Environmental Medicine, 69(4), 243-249. https://doi.org/10.1136/oemed-2011-100106

Chadambuka, A., Mususa, F., \& Muteti, S. (2013). Prevalence of noise-induced hearing loss among employees at a mining industry in Zimbabwe. African Health Science, 13(4), 899-906. https://doi.org/10.4314/ahs.v13i4.6

Chaisson, R.E., \& Martinson N.A. (2008). Tuberculosis in Africa - Combating an HIVdriven crisis. The New England Journal of Medicine, 358(11), 1089-1092. https:// doi.org/10.1056/NEJMp0800809

Cox, H., Reuter, A., Furin, J., \& Seddon, J. (2017). Prevention of hearing loss in patients with multidrug-resistant tuberculosis. The Lancet, 390(10098), 934. https://doi. org/10.1016/S0140-6736(17)32170-0 
Daniel, E. (2007). Noise and hearing loss: A review. Journal of School Health, 77(5) 225-231. https://doi.org/10.1111/j.1746-1561.2007.00197.x

Daudt, H.M., van Mossel, C., \& Scott, S.J. (2013). Enhancing the scoping study methodology: A large, inter-professional team's experience with Arksey and O'Malley's framework. BMC Medical Research Methodology, 13, 48. https://doi. org/10.1186/1471-2288-13-48

Edwards, A. (2009). 85 dBA: Is it protective enough to prevent hearing loss in South African miners? CSIR. Retrieved n.d., from http://www.saimm.co.za/Conferences/ HardRockSafety2009/251-264_Edwards.pdf

Edwards, A., Dekker, J.J., Franz, R.M., Van Dyk, T., \& Banyini, A. (2011). Profiles of noise exposure levels in South African mining. The Journal of the Southern African Institute of Mining and Metallurgy, 111(5), 315-322.

Eisler, R. (2003). Health risks of gold miners: A synoptic review. Environmental Geochemistry and Health, 25(3), 325-345.

Elgstrand, K., \& Vingård, E. (2013). Occupational safety and health in mining: Anthology on the situation in 16 mining countries. Gothenburg, Sweden: Occupational and Environmental Medicine, University of Gothenburg.

European Agency for Safety and Health at Work (EU-OSHA). (2009). Combined exposure to noise and ototoxic substances. Luxembourg: Office for Official Publications of the European Communities. Retrieved from https://osha.europa. eu/en/tools-and-publications/publications/literature reviews/combinedexposure-to-noise-and-ototoxic-substances

Fabry, D.A., Davila, E.P., Arheart, K.L., Serdar, B., Dietz, N.A., Bandiera, F.C., \& Lee, D.J. (2010). Second-hand smoke exposure and the risk of hearing loss. Tobacco Control, 20(1), 82-85. https://doi.org/10.1136/tc.2010.035832

Feder, K., Michaud, D., McNamee, J., Fitzpatrick, E., Davies, H., \& Leroux, T. (2017). Prevalence of hazardous occupational noise exposure, hearing loss, and hearing protection usage among a representative sample of working Canadians. Journal of Environmental and Occupational Medicine, 59(1), 92-113.

Freeman, M. (n.d.). Should non-communicable conditions of high burden but low mortality be prioritised in South Africa? Retrieved from https://www.google.com/url?sa=t\&rct $=j \& q=\& e s r c=s \&$ source $=$ web\& $\& d=1 \&$ ved $=2$ ahUKEwiF59yutt3jAhXWVBUIHZBFCwcQF jAAegQIABAC\&url=http\%3A\%2F\%2Fwww.health.gov.za\%2Findex.php\%2F2014-08 11-13-19-27\%3Fdownload\%3D89\%3Acommission-presentation-should-noncommunicable-conditions-of-high-burden-but-low-mortality-be-prioritised-in-southafrica-melvyn-freeman\&usg=AOVVawORbp3YZ7BRSOet6_6OnBfG

Gueler, A., Moser, A., Calmy, A., Günthardm H.F., Bernasconi, E., Furrer, H. ... Swiss National Cohort. (2017). Life expectancy in HIV-positive persons in Switzerland: Matched comparison with general population. AIDS, 31(3), 427-436. https://doi. Matched comparison with general pop
org/10.1097/QAD.0000000000001335

Hong, O., Kerr, M.J., Poling, G.L., \& Dhar, S. (2013). Understanding and preventing noise-induced hearing loss. Disease-a-Month, 59(4), 110-118. https://doi. noise-induced hearing loss. Disease-
org/10.1016/j.disamonth.2013.01.002

Institute for Health Metrics and Evaluation (IHME). (2018). Findings from the global burden of disease study 2017. Seattle, WA: IHME. Retrieved from https://www. healthdata.org/sites/default/files/files/policy_report/2019/GBD_2017_Booklet.pdf

Jantti, M., \& Cater-Steel, A. (2017). Proactive management of IT operations to improve IT services. Journal of Information Systems and Technology Management, 14(2), 191-218. https://doi.org/10.4301/S1807-17752017000200004

Joint United Nations Programme on HIV/AIDS. (2018). UNAIDS data 2018. Retrieved from https://www.unaids.org/sites/default/files/media_asset/unaids-data-2018_en.pdf

Khoza, K., \& Ross, E. (2002). Auditory function in a group of adults infected with HIV/ AIDS in Gauteng, South Africa. South African Journal of Communication Disorders, 49(1), 17-27. https://doi.org/10.4102/sajcd.v49i1.214

Khoza-Shangase, K. (2010a). Is there a need for ototoxicity monitoring in patients with HIV/AIDS? African Journal of Pharmacy and Pharmacology, 4, 574-579.

Khoza-Shangase, K. (2010b). HIV/AIDS and auditory function in adults: The need for intensified research in the developing world. African Journal of AIDS Research, 9(1), 1-9. https://doi.org/10.2989/16085906.2010.484531

Khoza-Shangase, K. (2011). Highly active antiretroviral therapy: Does it sound toxic? Journal of Pharmacy and Bioallied Sciences, 3(1), 142-153. https://doi org/10.4103/0975-7406.76494

Khoza-Shangase, K. (2017). Risk vs. benefit: Who assesses this in the management of patients on ototoxic drugs? Journal of Pharmacy and Bioallied Sciences, 9(3), 171-177. https://doi.org/10.4103/jpbs.JPBS_17_17

Khoza-Shangase, K. (2019a). Hearing function of gold miners with and without a history of tuberculosis: Treatment: A retrospective data review. Brazilian Journal
of Otorhinolaryngology, pii:S1808-8694(18)30189-7. https://doi.org/10.1016/j. of Otorhinolaryngold

Khoza-Shangase, K. (2019b). Pharmaco-audiology vigilance in the treatment of patients with HIV/AIDS: Ototoxicity monitoring protocol recommendation. Infectious Disorders - Drug Targets, 19(1), 1-9. https://doi.org/10.2174/1871526 Infectious Disorders - Drut
518666181016102102

Kistnasamy, B., Yassi, A., Yu, J., Spiegel, S., Fourie, A., Barker, S., \& Spiegel, J.M. (2018) Tackling injustices of occupational lung disease acquired in South African mines: Recent developments and ongoing challenges. Globalization and Health, 14, 78. https://doi.org/10.1186/s12992-018-0399-9

Krishnamurti, S. (2009). Sensorineural hearing loss associated with occupational noise exposure: Effects of age-corrections. International Journal of Environmental Research and Public Health, 6(3), 889-899.

Landier, W. (2016). Ototoxicity and cancer therapy. Cancer, 122(11), 1647-1658. https://doi.org/10.1002/cncr.29779

Lavinsky, J., Ge, M., Crow, A.L., Pan, C., Wang, J., Salehi, P., ...Friedman, R.A. (2016) The Genetic Architecture of Noise-Induced Hearing Loss: Evidence for a Gene-byEnvironment Interaction. G3 (Bethesda, Md.), 6(10), 3219-3228. https://doi. org/10.1534/g3.116.032516
Levac, D., Colquhoun, H., \& O'Brien, K.K. (2010). Scoping studies: Advancing the methodology. Implementation Science, 5(1), 69. https://doi.org/10.1186/17485908-5-69

Li, H., \& Steyger, P.S. (2009). Synergistic ototoxicity due to noise exposure and aminoglycoside antibiotics. Noise \& Health, 11(42), 26-32. https://doi.org/ 10.4103/1463-1741.45310

Lonsbury-Martin, B.L., \& Martin, G.K. (2001). Evoked otoacoustic emissions as objective screeners for ototoxicity. Seminars in Hearing, 22(4), 377-392. https:// doi.org/10.1055/s-2001-19111

Matas, C.G., Angrisani, R.G., Magliaro, F.C., \& Segurado, A.A. (2014). Audiological manifestations in HIV-positive adults. Clinics, 69(7), 469-475. https://doi. org/10.6061/clinics/2014(07)05

Miah, M.S., Rubya, S., \& Kabir, M.F. (2014). Assessment of occupational noise induced hearing loss via a smartphone application. The 8th International Conference on Software, Knowledge, Information Management and Applications (SKIMA 2014), (pp. 1-5)

Minerals Council South Africa. (2018). Masoyise ITB project (Minerals Council South Africa Masoyise ITB Project Data Report 2018). Retrieved from https://www. mineralscouncil.org.za/component/jdownloads/send/53-reports-and-annexures2018/774-data-report-2018

Mostaghaci, M., Mirmohammadi, S.J., Mehrparvar, A.H., Bahaloo, M., Mollasadeghi, A., \& Davari, M.H. (2013). Effect of workplace noise on hearing ability in tile and ceramic industry workers in Iran: A 2-year follow-up study. The Scientific World Journal, 2013(923731), 1-7. https://doi.org/10.1155/2013/923731

Nandi, S.S., \& Dhatrak, S.V. (2008). Occupational noise-induced hearing loss in India. Indian Journal of Occupational Environmental Medicine, 12(2), 53-56. https://doi. org/10.4103/0019-5278.43260

Nelson, D.I., Nelson, R.Y., Concha-Barrientos, M., \& Fingerhut, M. (2005). The global burden of occupational noise-induced hearing loss. American Journal of Industrial Medicine, 48(6), 446-458. https://doi.org/10.1002/ajim.20223

Olu, T., Youngblood, E., Boulle, A., McGrath, N., Wilkinson, R.J., \& Levitt, N.S. (2015). Patterns of HIV, TB and non-communicable disease multi-morbidity in peri-urban
South Africa: A cross-sectional study. BMC Infectious Disease, 15(20), 15-20. South Africa: A cross-sectional study. BMC
https://doi.org/10.1186/s12879-015-0750-1

Patel, D.S., Witte, K., Zuckerman, C., Murray-Johnson, L., Orrego, V., Maxfield, A.M., ... Thimons, E.D. (2010). Understanding barriers to preventive health actions for occupational noise-induced hearing loss. Journal of Health Communication, 6(2), 155-168. https://doi.org/10.1080/10810730120042

Pillay-van Wyk, V., Msemburi, W., Laubscher, R., Dorrington, R.E., Groenewald, P., Glass, T ... Bradshaw, D. (2016). Mortality trends and differentials in South Africa
from 1997 to 2012: Second national burden of disease study. The Lancet Global Health, 4(9), e642-e653. https://doi.org/10.1016/S2214-109X(16)30113-9.

Rappaport, J.M., \& Provencal, C. (2001). Neuro-otology for audiologists. In J. Katz (Ed.), Handbook of clinical audiology (5th edn., pp. 9-32). Baltimore, MD: Lippincott Williams \& Wilkins.

Reddy, M., \& Swanepoel, B. (2006). Cutting the cost of HIV/AIDS. Retrieved n.d., from http://www.deloitte.com/assets/DcomSouthAfrica/Local\%20Assets/Documents/ HIVAIDS_Deloitte.pdf.

Ritzel, D.O., \& McCrary-Quarles, A.R. (2008). Hearing loss prevention and noise control. Umwelt und Gesundheit, 1, 22-29.

Rohde, J., Cousens, S., Chopra, M., Tangcharoensathien, V., Black, R., Bhutta, A.Z., \& Lawn, J.E. (2008). 30 years after Alma-Ata: Has primary health care worked in countries? Lancet, 372(9642), 950-961. https://doi.org/10.1016/S0140-6736(08)61405-1

Sibanye Gold. (2018). Occupational health and well-being. Retrieved from https:// reports.sibanyegold.co.za/2018/download/SGL-IR18-occupational-healthwellbeing.pdf

Singh, K. (2017). Over 100 TB patients go deaf because of negligence. News 24 Retrieved from https://www.news24.com/SouthAfrica/News/over-100-tbpatients-go-deaf-because-of-negligence-da-20170906

Statistics South Africa (2018). Mid-year population estimates. Retrieved from https:// www.statssa.gov.za/publications/P0302/P03022017.pdf

Stevinson, C., \& Lawlor, D. (2004). Searching multiple databases for systematic reviews: Added value or diminishing returns? Complementary Therapies in Medicine, 12(4), 228-232.

Strauss, S., Swanepoel, D.W., Becker, P., Eloff, Z., \& Hall, J.W., III. (2014). Noise and agerelated hearing loss: A study of 40,123 gold miners in South Africa. Internationa Journal of Audiology, 53(Suppl 2), S66-S75. https://doi.org/10.3109/14992027.2 013.865846

Stuckler, D., Basu, S., McKee, M., \& Lurie, M. (2011). Mining and risk of tuberculosis in sub-Saharan Africa. American Journal of Public Health, 101(3), 524-530. https:// doi.org/10.2105/AJPH.2009.175646

Stuckler, D., Steele, S., Lurie, M., \& Basu, S. (2013). 'Dying for gold': The effects of mineral mining on HIV, tuberculosis, silicosis and occupational diseases in
southern Africa. International Journal of Health Services: Planning, Administration, Southern Africa. International Journal of Health Services: Planning
Evaluation, 43(4), 639-649. https://doi.org/10.2190/HS.43.4.c

Valente, M., Hosford-Dunn, H., \& Roeser, R.J. (2008). Audiology: Treatment (2nd edn.). New York, NY: Thieme.

Viera, A.J., \& Garreth, J.M. (2005). Understanding inter-observer agreement: The Kappa statistics. Family Medicine, 37(5), 360-363.

Wilson, B.S., Tucci, D.L., Merson, M.H., \& O’Donoghue, G.M. (2017). Global hearing health care: New findings and perspectives. Lancet, 390(10111), 2503-2515. https://doi.org/10.1016/S0140-6736(17)31073-5

World Health Organisation (WHO). (2018). Addressing the rising prevalence of hearing loss. Retrieved from https://apps.who.int/iris/bitstream/handle/10665/260336/ 9789241550260-eng. pdf; jsessionid=13FFE7CCEC3FE3335FD451FA5132CBD4?se quence $=1$ 